\title{
Stabilita stoja po únave brušných svalov
}

\section{Stability of standing after abdominal muscules fatigue}

\author{
Daniel Gurín, Jan Novotný
}

Fakulta sportovních studií, Masarykova univerzita Brno

\begin{abstract}
Abstrakt:
$V$ rámci pilotnej experimentálnej štúdie bolo testovaných 8 mužov s priemerným vekom $33,5 \pm 3,64$ roka. Probandi boli testovaný na Biodex balance system pred a po cvičenízameranom na brušné svaly. Cvičenie bolo vykonávané do subjektívne vnímaného maxima. Súbor bol zámerne zostavený z jedincov psychicky aj fyzicky trénovaných. Hodnotený bol index stability, čím je nominálna hodnota menšia tým je stabilita lepšia. Po cvičení boli parametre stability signifikantne horšie ako pred cvičením $(p=0,025)$. Únava brušných svalov teda negatívne ovplyvňuje stabilitu stoja.
\end{abstract}

\begin{abstract}
:
In the pilot experimental study eight men with an average age of $33.5 \pm 3.64$ years were tested. The probands were tested on the Biodex Balance System before and after the exercise of the abdominal muscles. Exercise was carried out to the subjectively perceived maximum. The file was deliberately composed of mentally and physically trained individuals. Evaluated was the stability index, the smaller the nominal value, the better the stability. After the workout stability parameters were significantly worse than before the exercise $(p=0.025)$. The fatigue of the abdominal muscles thus negatively affects the stability of the stand.
\end{abstract}

Klúčové slová:

stabilita stoja, svalová únava, brušné svaly, postúra, Biodex balance.

Key words:

Stability of standing. Muscular fatigue. Abdominal muscles. Posture. Biodex balance.

\section{ÚVOD}

Brušné svaly, ako súčast' híbkového stabilizačného systému, ale aj ako svaly priamo ovplyvňujúce postavenie hrudníka a panvy sú svojou funkciou nezastupitel'né pre prevedenie kvalitných pohybov, či lokomócie. Ich význam dokazuje vel'ké množstvo štúdií. Napríklad pri rýchlom pohybe ramena bola dokázaná koaktivácia m.transverzus abdominis a m. obliquus internus abdominis (Masse-Alaire, Flamand, Moffet \& Schneider 2012). McGill, Karpowicz, \& Fenwick (2009) hovoria o zapojení brušných svalov pred akýmkol'vek pohybom. Pre fyziologickú vyváženost' držania tela má zásadný význam postavenie panvy. Prostredníctvom svalových ret’azcov je obojstranne funkčné spojenie s panvou a udržiavaním opory nohy pri kontakte s podložkou. Do postavenia panvy sa premietajú odchýlky z končatín aj trupu (Kolár̆, 2009, p.45).

Funkciu brušných svalov ovplyvňuje vel’a faktorov. štúdia je zameraná na jeden z limitujúcich faktorov a to subjektívne vnímanú únavu. Rôzne štúdie hovoria o vzt’ahoch únavy stabilizačných svalov a postúry. Súvislost' únavy krčných svalov so zabezpečením stoja dokladujú vo svojej štúdii Vuillerme, Pinsault \& Vaillant (2005), vplyv únavy stabilizátorov trupu na priemet t'ažiska popisujú autori v d’alších dvoch výskumných prácach (Bašič, Strojnik \& Rugelj 2013, Parreirra, Amorim, ... \& da Silva, 2013).

Ciel'om našej štúdie bolo zistit' vplyv únavy brušných svalov na stabilitu stoja. Ďalej sme chceli zistit' vzt'ahy medzi indexom stability, somatometrickými a funkčnými parametrami 


\section{METODIKA}

Súbor tvorilo 8 jedincov zo špecializovaného útvaru s priemerným vekom 33,5 so smerodajnou odchýlkou $(\mathrm{SD}) 3,64(\mathrm{~min}=28, \max =38$ rokov). Priemerná výška v súbore bola 175,88 $(\mathrm{SD}=7,1$, $\min =167, \max =189)$, hmotnost' $84,25(\mathrm{SD}=11,55, \min =63, \max =104)$ a BMI $27,11(\mathrm{SD}=2,17$, $\min =22,59, \max =30,08$ ).

Pred testovaním probandi absolvovali komplexné vyšetrenie pozostávajúce zo zátažového testu (spiroergometria) z pokojovej spirometrie, antropometrického merania, merania hemodynamických parametrov a percenta tuku $v$ tele.

Pre objektivizáciu nášho zámeru sme zvolili prístroj Biodex balance system SD model 945-300 (obrázok 1).

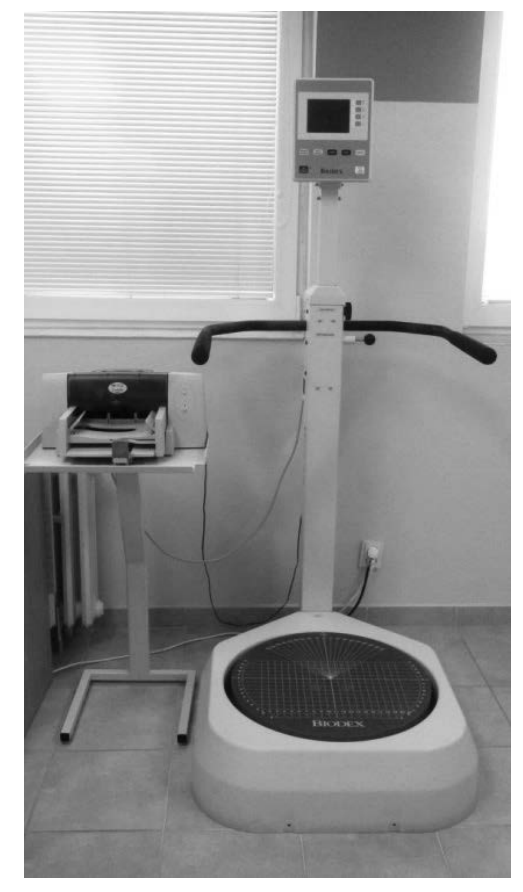

Obrázok 1. Biodex balance system SD

Základným výstupným parametrom je index stability. Čím je nominálna hodnota výstupu nižšia tým je stabilita lepšia. Ak sa index stability rovná 0 ide o ideálnu stabilitu, plošina sa počas testu nepohne, je to však len hypotetická prakticky nereálna hodnota. Stúpajúca hodnota indexu stability hovorí o stále horšej stabilite, plošina sa viac vychyl'uje.

Na základe štúdie (Wendy, 2009) kde výsledky uvádzajú že pre testovanie vyšiel najreliabilnejšie postup s dvomi predtestami a dvomi vlastnými testami, zvolili sme postup jedného merania spolu s predtestom a následne dvomi meraniami, z ktorých priemerná hodnota bola smerodajná pre porovnávanie s výstupným testom.. Po verbálnej edukácii probanda nasledovala názorná edukácia s absolvovaním prvého testu, ktorý nebol započítaný do štatistických výsledkov, ale výslednú hodnotu sme využili pre potvrdenie vylúčenia tréningového efektu. Ďalej nasledovali dve testovania z časovým odstupom. Nasledovala pohybová aktivita v l'ahu. Bezprostredne po dosiahnutí požadovanej úrovne nasledoval výstupný test na prístroji Biodex balance system. Výstupné meranie bolo zahájené maximálne do 30 sekúnd od ukončenia cvičenia. Výstupný test sme vykonávali len jeden z dôvodu rýchleho doplnenia zásob ATP a jeho obnovy z kreatinfosfátu, čo by mohlo ovplyvnit' následné testovanie. 
Testované osoby boli vyšetrované na boso. Na základe predtestu bola určená a zaznamenaná poloha dolných končatín, ktorá bola použitá pre všetky nasledujúce testy vrátane výstupného testu. Predtest slúžil na zvolenie si optimálnej polohy nôh pre čo najlepšiu stabilitu na labilnej plošine. Ostatné merania u jednotlivých probandov boli vykonávané bez predtestu. Poloha chodidiel bola zaznamenaná s pomocou súradníc a uhla odklonu chodidla od strednej čiary. Testy boli vykonávané na úrovni lability 5 čo je stredne labilná plošina. Tento stupeň sme zvolili z toho dôvodu, že výsledky odborných štúdií pracujúcich s Biodex balance systémom hovoria o tom, že na najstabilnejšom stupni je možné dosiahnut' zlepšenie aj len na základe opakovania testovania pričom u labilnejších stupňov je nutný prídavný tréning na dosiahnutie signifikantného zlepšenia. Stupeň 5 sme vybrali aj preto, že sa používa pri testovaniach. Patrí do stredne labilnej až labilnej zát'aže. Na najstabilnejšom stupni bol zaznamenaný tréningový efekt (Lephart, Pincivero \& Henry, 1995), a najlabilnejší stupeň sa na testovanie neodporúča (Cug \& Wikstrom, 2014), preto sme volili labilitu v strede spektra. Použili sme štandardný 20 sekúnd trvajúci test. Testy boli vykonávané pri zrakovej kontrole. Proband videl pred sebou displej s kruhovým terčom a pokúšal sa udržat' čo najstabilnejší postoj tak, aby sa zobrazený krížik nachádzal čo najviac v strede terčíka na displeji počas celého testu. Test bol platný, ak proband vydržal na testovacej plošine v bipedálnom stoji celých 20 sekúnd, bez dotyku oporného zariadenia, alebo akejkolvek inej pomoci.

Pohybová aktivita vykonávaná pred výstupným testovaním bola opakovaná flexia trupu za presne stanovených podmienok. Proband ležal na tvrdej žinenke v polohe na chrbte. Dolné končatiny mal uvol'nené a položené na stoličke. Poloha dolných končatín bola približne v $90^{\circ}$ flexii v bedrových a kolenných kĺboch, tak aby panva zaujímala neutrálne postavenie. Členkové kíby boli uvol'nené, zaujímali pasívnu polohu $\mathrm{v}$ danej situácii. Takáto poloha dolných končatín bola zvolená na základe snahy o čo najväčšie vyradenie flexorov bedrového kíbu zo synergie na flexii trupu. Napriek polohe sa zapája m. quadratus lumborum a m. iliopsoas, ktorých úplné vyradenie nie je možné, nakol'ko pracujú ako stabilizátory. Flexia trupu bola vykonávaná v rozsahu skracovania sa m. rectus abdominis, teda po odlepenie dolného uhla lopatiek. Probandi boli pri vykonávaní cvičenia kontrolovaní a usmerňovaní. Cvičenie bolo prevádzané pomaly, bez švihovej komponenty s rukami za hlavou. Cvičenie bolo kontinuálne v jednej sérii po dosiahnutie subjektívne vnímaného maxima, čo znamenalo neschopnost' probanda vykonat' d'alšie opakovanie flexie trupu v požadovanom rozsahu. Proband teda nebol schopný ohnút' trup tak aby dokázal odlepit' spodný uhol lopatky.

Pri dosiahnutí spomínaného stavu sa proband postavil a nasledoval výstupný test na Biodex balance system. Postavenie bolo tiež koordinované cez polohu na boku a potom pozíciu cez kolená. Testovaní boli upozornení na to, aby nevstávali vel'mi rýchlo. Tesne pred začatím testu sme žiadali od testovaných uistenie o tom, že sú pripravený na test, že sa im nekrúti hlava v dôsledku možnej zmeny tlaku krvi po náhlej zmene polohy, čím sme sa snažili predíst' možnému ortostatickému kolapsu.

Výstupné testovanie bolo prevedené podl'a spomínaných kritérií s postojom probanda upravenom na základe súradníc a uhla postavenia chodidiel získaných z predtestu. Po ukončení výstupného testu nasledoval krátky rozhovor zameraný hlavne na subjektívne pocity testovaného a jeho hodnotenie situácie po intervencii pohybovou aktivitou.

Pre vyhodnotenie sme porovnávali hodnoty indexu stability pred a po cvičení. Ďalej sme hladali súvislosti medzi somatometrickými parametrami, funkčnými parametrami a parametrami stability.

Pre všetky štatistické testovania sme zvolili hladinu významnosti $\alpha=0,05$. Normalitu dát sme testovali Shapiro-Wilkovým a Kolmogorov-Smirnovým testom. Pri normálnom rozdelení dát sme použili t-test. $Z$ dôvodu malého počtu probandov sme testovali aj neparametrickou variantov a teda Wilcoxonovým testom. Tesnost' vzt'ahu medzi sledovanými premennými bola zist'ovaná testom korelácie s výpočtom korelačného koeficientu. Pre štatistické výpočty sme použili program Statistica 12. 


\section{VÝSLEDKY}

V rámci vstupných testov sme vyhodnotili aj sledované funkčné parametre. Metabolický ekvivalent pri vstupnej spiroergometrii bol 12,81 $\pm 1,76$. Výsledky spirometrie hovoria o dobrej funkcii pulmonálneho systému. FVC-5,32 \pm 0,59, FEV-4,55 $\pm 0,83$, VC-5,54 $\pm 0,84, \mathrm{MVV}-132,93 \pm 26,44$.

Výsledky experimentálnej časti boli prekvapujúce hlavne v dĺžke času vykonávania cvičenia. Priemerná dížka cvičenia bola 38 minút a ak vylúčime extrémnu hodnotu 4:22 tak 43 minút. Traja probandi sa dostali nad hranicu 60 minút, maximum bolo 61 minút 18 sekúnd. Pri testovaní boli probandi nabádaní prekonat' výkon svojho velitel'a (33 minút). Ukázalo sa, že to bol silne motivačný prvok. Všetci, čo dosiahli 30 minút a viac opisovali 12 až 15 minútu ako prvú bariéru, kedy si mysleli že už d'alej nemôžu, ked' však prekonali tento moment boli schopný pokračovat' ešte niekol'konásobne dlhšie. Je potrebné pripomenút', že probandi boli členmi špecializovanej jednotky a sú teda fyzicky aj psychicky trénovaní prekonávat' bariéry.

Výsledky vlastných testovaní súboru s hodnotami indexu stability zobrazuje tabul'ka 1 . Probandi dosiahli pri vstupnom teste priemernú hodnotu indexu stability $2,08(\mathrm{SD}=0,80)$ a pri výstupnom teste $2,71(\mathrm{SD}=0,98)$. Okrem iného to naznačuje dobrú úroveň stability v súbore.

Tabulka 1 Popisné výsledky testovania skupiny špecialistov.

\begin{tabular}{|l|c|c|c|c|c|}
\hline Index stability & Test $\mathbf{0}$ & Test $\mathbf{1}$ & Test 2 & Vstupný test & Výstupný test \\
\hline aritmetický priemer & 2,06 & 2,05 & 2,11 & $\mathbf{2 , 0 8}$ & $\mathbf{2 , 7 1}$ \\
\hline Medián & 2,3 & 1,95 & 2,4 & $\mathbf{2 , 3}$ & $\mathbf{2 , 6 5}$ \\
\hline smerodajná odchylka & 0,61 & 0,86 & 0,86 & $\mathbf{0 , 8 0}$ & $\mathbf{0 , 9 8}$ \\
\hline $\mathbf{N}$ & 8 & 8 & 8 & $\mathbf{8}$ & $\mathbf{8}$ \\
\hline Súčet & 16,5 & 16,4 & 16,9 & $\mathbf{1 6 , 6 5}$ & $\mathbf{2 1 , 7}$ \\
\hline minimum & 1,2 & 0,9 & 1,1 & $\mathbf{1}$ & $\mathbf{1 , 2}$ \\
\hline Maximum & 2,8 & 3,2 & 3,2 & $\mathbf{2 , 9 5}$ & $\mathbf{4 , 4}$ \\
\hline dolný kvartil & 1,45 & 1,35 & 1,15 & $\mathbf{1 , 2 5}$ & $\mathbf{2 , 1 5}$ \\
\hline horný kvartil & 2,5 & 2,85 & 2,75 & $\mathbf{2 , 8}$ & $\mathbf{3 , 2 5}$ \\
\hline
\end{tabular}

Priemer indexov stability vo výstupnom teste bol už výrazne vyšší a dokladoval zhoršenie priemeru v skupine, čo bolo očakávaným výsledkom. Brušné svaly tvoria vel'mi významnú súčast' posturálnej stability ako stabilizátory driekovej chrbtice z ventrálnej a laterálnej strany. 


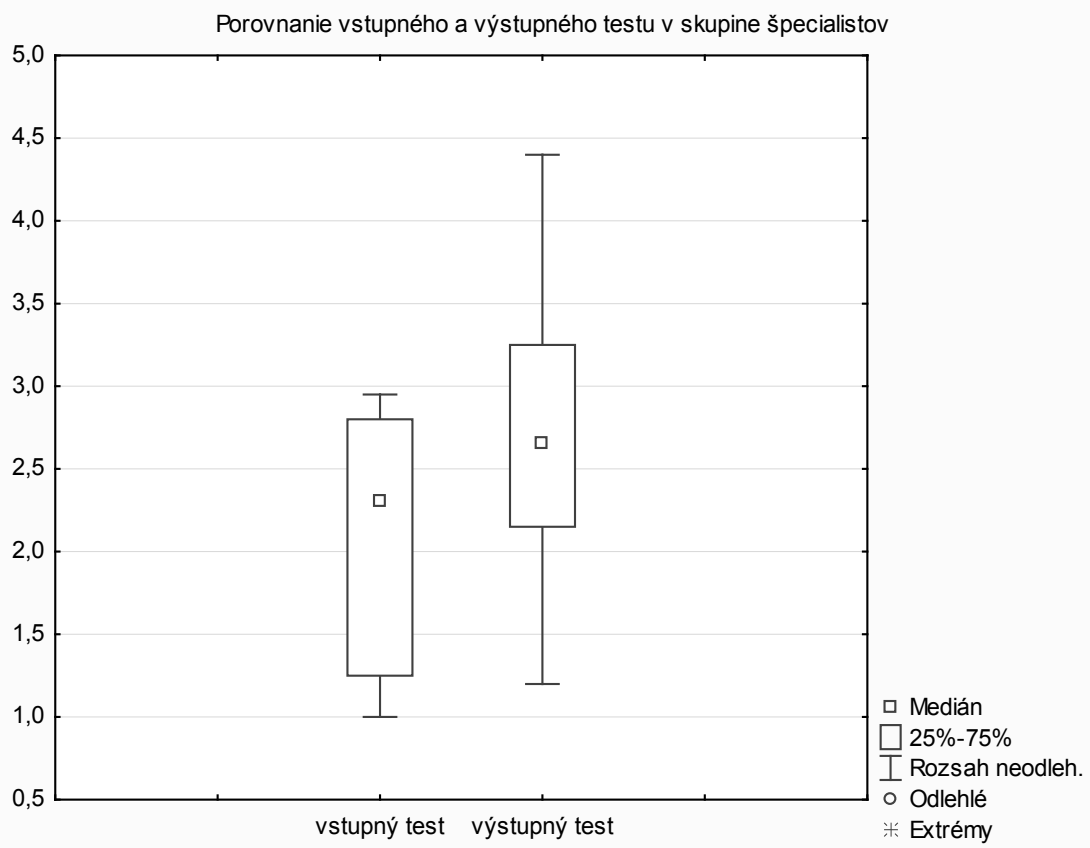

Obrázok 2 Index stability pred a po zátaži, medián

Porovnanie výsledkov vstupných a výstupných testov v skupine špecialistov, medián

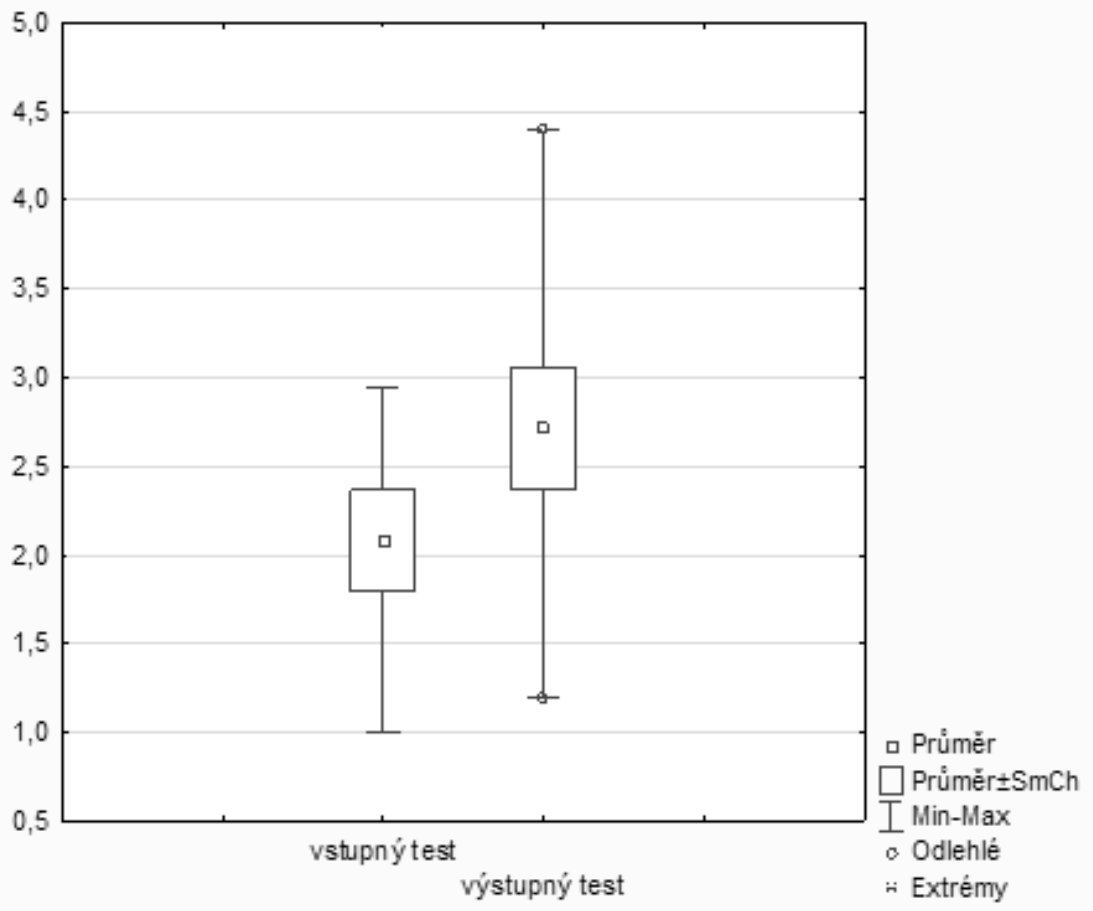

Obrázok 3 Index stability pred a po zátaži, aritmetický priemer 
Grafické znázornenie hodnôt indexu stability a to mediánu (obrázok 2) a aritmetického priemeru (obrázok 3) zobrazujú príslušné grafy. Na základe normálneho rozdelenia dát testovaných ShapiroWilkovým testom $\mathrm{W}>$ kritická hodnota (kritická hodnota 0,818 pre $\alpha=0,05$, vstupný test $\mathrm{w}=0,867$, výstupný test $\mathrm{w}=0,96)$, aj Kolmogoro-Smirnovým testom $(\mathrm{d}=0,18934,0,21455)$ testujeme t-testom. Výsledok je štatisticky významný na zvolenej hladine významnosti $(\mathrm{p}=0,020634)$.

Na základe malého počtu probandov sme ešte testovali aj neparametrickým testom (Wilcoxonov párový test). Výsledky testu ukazujú signifikantný rozdiel v prospech vstupného testu $\mathrm{p}=0,025$. Štatisticky významné boli aj rozdiely výstupného testu voči nultému $(\mathrm{p}=0,043)$ a prvému testu $(\mathrm{p}=0,028)$. Medzi výsledkami druhého a výstupného testu nebol zaznamenaný štatisticky významný rozdiel na sledovanej hladine významnosti $(\mathrm{p}=0,069)$.

Vysoká korelačná závislost' medzi percentom tuku a BMI $(\mathrm{r}=0,93)$ naznačuje, že probandi majú reálne nadváhu. Ďalšie korelačné súvislosti sú zobrazené v tabul'ke 2 . Závislost' výšky a indexu stability bola však signifikantná len pri vstupnom teste, pri výstupnom teste sme zaznamenali len strednú závislost'. Pri porovnaní metabolického ekvivalentu sa ukázala štatisticky významná nepriamoúmerná závislost's indexom stability pri vstupnom teste, teda čím bola dosiahnutá nižšia výkonnost' pri spiroergometrickom vyšetrení, tým bol vyšší index stability, teda horšia schopnost' udržiavania stabilného stoja. Statické dychové parametre získané spirometrickým vyšetrením a index stability pred aj po cvičením vykazovali len strednú mieru závislosti. Korelácia indexu stability BMI a percenta tuku bolo pri vstupnom teste na úrovni strednej závislosti, ale po cvičení medzi spomínanými parametrami vzt'ah vymizol.

Tabulka 2 Korelačné koeficienty indexu stability vstupných a výstupných testov s jednotlivými parametrami

\begin{tabular}{|l|c|c|c|c|c|c|c|c|c|c|}
\hline & Vek & výška & hmotnost' & BMI & Tuk & MET & FVC & FEV & VC & MMV \\
\hline vstupný test & $-0,40$ & $0,77^{*}$ & $0,73^{*}$ & 0,49 & 0,44 & $-0,71^{*}$ & 0,41 & 0,26 & 0,54 & $-0,49$ \\
\hline výstupný test & $-0,41$ & $0,73^{*}$ & 0,45 & 0,02 & 0,09 & $-0,39$ & 0,42 & 0,01 & 0,31 & $-0,51$ \\
\hline
\end{tabular}

MET - metabolický ekvivalent

FVC - force vital capacity, úsilná vitálna kapacita

FEV - forcing expiratory volume, objem usilovného výdychu za jednu sekundu

VC - vital capacity, vitálna kapacita

MVV - maximal minute volume, maximálna minútová ventilácia

* štatisticky významné hodnoty na zvolenej hladine významnosti

\section{DISKUSIA}

Negatívny dopad únavy svalov ovplyvňujúcich postúru dokazuje viacero štúdií. Parreira et al vo svojej štúdii s 36 testovanými osobami dokázal súvislost' zmeny postavenia a priemetu t’ažiska v závislosti od únavy stabilizátorov trupu, v tomto prípade extenzorov trupu (Parreirra, Amorim, Gil, Teixeira, Bilodeau, \& da Silva, 2013). Ďalšia štúdia sa snaží o determináciu efektu únavy extenzorov chrbtice na pohyb t’ažiska v závislosti od veku. Súbor tvorilo 14 starších a 16 mladších probandov. Výsledky popisujú rozdiel len medzi testovaním s kontrolou a bez kontroly zraku nakol'ko rozdiel v pohybe t’ažiska v závislosti od veku preukázaný nebol (Bašič, Strojnik, \& Rugelj, 2013). My sme dokázali podobný efekt pri vyvolaní únavy brušných svalov a teda zhoršenie stoja na labilnej plošine. Probandi pri cvičení prekročili subjektívnu bariéru únavy, čo im umožnilo dosiahnut' reálnu únavu svalov. Je dôležité si tento fakt uvedomit', pretože pri testovaní probandov po dosiahnutie subjektívneho maxima je možné dosiahnut' naopak zlepšenie stability stoja (Gurín, 2014).

Zaujímavé sú však súvislosti, ktoré naznačujú korelačné vzt’ahy medzi premennými. Hlavne sa jedná o parametre l'udského tela ako hmotnost', či pomer hmotnosti a výšky, teda Body mass index. 
Klinické štúdie potvrdzujú vplyv BMI na posturálnu stabilitu (Hamilton, 2015, Kováčiková, Svoboda \& Janura, 2014). V našom súbore sme zaznamenali strednú závislost' BMI a indexu stability počas vstupného testu. Pri porovnaní výstupných testov sme ale žiadnu závislost' nepreukázali $(\mathrm{r}=0,02)$. Dôvodom môže byt', že jedinci s vyšším BMI mali aj nižšiu hodnotu MET pri vstupnom spiroergometrickom vyšetrení a teda pri cvičení do subjektívne vnímaného maxima dosiahli nižší stupeň únavy brušných svalov, čo tak výrazne nezasiahlo do posturálnych mechanizmov. Vzt'ah percenta tuku a indexu stability bol takmer zhodný s výsledkami pomeru BMI a indexu stability, čo potvrdzuje, že probandi s vyšším BMI mali skutočne nadváhu. Rovnako to bolo s hmotnost'ou, kedy porovnanie hmotnosti a vstupných testov bolo signifikantné, výstupné testy sa nachádzali v oblasti strednej závislosti, rovnako ako porovnanie metabolického ekvivalentu s indexom stability. Signifikantný vzt'ah indexu stability a výšky môže byt' zapríčinený vy̌šsou polohou t'ažiska i ked' pri väššom súbore sme takúto závislost' nepreukázali (Gurín, Novotný, Gurín Gabl'asová, 2015). Limitujúcim faktorom štúdie bol aj nízky počet probandov.

\section{ZÁVERY}

Fyziologická únava slúži na vyvolanie adaptačných mechanizmov. Zmena v riadení postúry sa však môže prejavit' okamžite. Pri vysokej zát'aži vyvolávajúcej únavu brušných svalov môže mat' cvičenie brušných svalov negatívny vplyv na udržanie stabilného stoja. Zaujímavým zistením je vzt’ah nadváhy reprezentovaný v našom súbore BMI nad $25 \mathrm{~kg} / \mathrm{m}^{-2}$ a percentom tuku vyšším ako 15 na index stability. Zatial' čo v pokojovom stave tieto parametre negatívne ovplyvňujú index stability, po únave brušných svalov sa takáto súvislost' stráca.

\section{Literatúra}

Bašič, D., Strojnik, V \& Rugelj, D. (2013) The efect of back muscle fatigue on postural sway. Kinesiologia Slovenica. 19, 2, 5-16, ISSN 1318-2269.

Cug, M \& Wikstrom, E. A. (2014) Learning Effects Associated With the Least Stable Level of the Biodex Stability System During Dual and Single Limb Stance. Journal of Sports Science \& Medicine. Vol. 13. Issue 2, p 387

Gurín, D., Novotný, J. \& Gurín Gablasová, M. (2015) Limitujúce faktory stability stoja. Zdravotnícke listy. roč. 3, č. 3, s. 7-10. ISSN 1339-3022

Gurín, D. (2014) Význam brušných svalov v posturálnom zabezpečení stoja Fyzioterapia, rehabilitácia a regenerácia Pohyb, hudba a zdravie. Zborník príspevkov z medzinárodnej vedeckej konferencie - Trenčín: Fakulta zdravotníctva, Trenčianska univerzita Alexandra Dubčeka v Trenčíne, 2014. s. 19-23. ISBN 978-80-8075-644-4

Hamilton, M., Strawderman. L., Hale, B \& Babski-Reeves K. (2015) Effects of BMI and task parameters on postural sway during simulated small parts assembly. Ergonomics.;58(3):504-12. doi: 10.1080/00140139.2014.972468

Lephart, S.M., Pincivero, D. Henry, T.J. (1995) Learning effects and reliability of the Biodex Stability System. Journal of Athletic Training; 30:S35

Parreira. R. B., Amorim, F., Gil, A. W., Teixeira, D.C., Bilodeau, M \& da Silva, R. A. (2013). Effect of trunk extensor fatigue on the postural balance of elderly and young adults during unipodal task. European Journal of Applied Physiology, 113. ISSN 1439-6327

Kolář, P. (2009). Rehabilitace v klinické praxi. Praha: Galen. ISBN 978-80-7262-657-1

Kováčiková, Z; Svoboda, Z; Neumannová, K; Bizovská, L; Cuberek, R \& Janura, M, (2014) Assessment of postural stability in overweight and obese middle-aged women. Acta Gymnica, Vol. 44 Issue 3, p149

Massé - Alaire, H., Flamand, V. H., Moffet, H. \& Schneider, C. (2012). Corticomotor control of deep abdominal muscles in chronic low back pain and anticipatory postural adjustments. Experimental Brain Research., s. 99-109, Springer. ISSN: 1432-1106

McGill, S.M., Karpowicz, A., \& Fenwick, C. (2009) Muscle activation patterns during three activities along the stability/ mobility continuum.Journal strenght and conditioning research, 23,3 898-905. ISSN: 1533-4287

Wendy, J. C., Shifflett, B., Kahanov, L. \& Wughalter, E. H. (2001). Reliability of Biodex Balance System measures. Measurement in physical education and exercise science, vol 5, iss 2

Vuillerme, N., Pinsault, N., \& Vaillant, J. (2005) Postural control during quiet standing following cervical muscular fatigue: effects of changes in sensory inputs. Neuroscience Letters 378, 3 135-9, ISSN: 0304-3940 